\title{
Relasi Budaya Arab-Melayu dalam Sejarah di Indonesia
}

\author{
M. Dien Madjid
}

\begin{abstract}
This research reveal about culture of Arab-Malay could not escape the series of Islamization that is not separated from the contribution of the Arab nation. From man of the desert this is Islam exuberantly and check in Malay. His natural aridity, does not affect the subtlety of the attitude and friendliness of speak so unable to convince the population of the Islands for religious Unity. Of those entities in order to at maturity, and can synergize with the global community. The synergy of trade-Da'wah is no longer the offensive problems of Commerce, here in after have led to the phenomenon of history to mixture of both cultures.

People Arabic or Malay has a cultural attachment that cannot be released. This makes the second Southeast Asian ethnic group as a vehicle of Islamic civilization in the other country of origin faced. In the regional area, nesting and Islamic showed to its light able to be felt until the present. Culture that woke up, became the unifying node that displays an openness and smoothness is maintained in a long time. This paper will peel back the issue of how Arab-Malay articulation happen and dialectical.
\end{abstract}

Keyword : Society, Arab-Malay, culture, civilization, acculturation

\begin{abstract}
Penelitian ini mengungkap tentang kebuadaayan Arab-Melayu tidak bisa lepas dari rangkaian Islamisasi yang tidak lepas dari kontribusi bangsa Arab. Dari manusia padang pasir inilah Islam merimbun dan menyemak di lingkungan Melayu. Kegersangan alam tempat tinggalnya, tidak mempengaruhi kehalusan sikap dan keramahan bertutur sehingga mampu meyakinkan penduduk kepulauan untuk beragama Tauhid. Dari mereka entitas kemelayuan sampai pada maturitas, hingga dapat bersinergi dengan komunitas global. Sinergi dagang-dakwah bukan lagi menyinggung masalah perniagaan, selanjutnya telah membawa pada fenomena menyejarah yakni percampuran budaya keduanya.

Orang Arab maupun Melayu memiliki keterikatan kultural yang tidak bisa dilepaskan. Kedua etnis ini menjadikan Asia Tenggara sebagai wahana tampilnya peradaban Islam yang berwajah lain dari negeri asalnya. Di kawasan regional tersebut, Islam bersarang dan menerang hingga sinarnya mampu dirasakan hingga masa kini. Budaya yang terbangun, menjadi simpul pemersatu yang menampilkan kehalusan dan keterbukaan yang terjaga di waktu yang lama. Makalah ini akan mengupas masalah bagaimana akluturasi Arab-Melayu terjadi dan berdialektika.
\end{abstract}

Kata Kunci : Masyarakat, Arab-Melayu, Budaya, Peradaban, Akulturasi 


\section{A. Pendahuluan}

Etnis Melayu memiliki harta sejarah yang amat melimpah. Serpihan demi serpihan yang diciptakan setiap masanya membentuk gunung gemunung keteladanan serta kisah yag tak habis diceritakan. Identitas mereka amat kental mewarnai Asia Tenggara, hingga menjadi etnis yang paling menonjol perannya. Posisi tersebut tidak dapat diraih dalam sekejap mata, melainkan suatu hasil dari pergumulan peradaban yang panjang dan lama.

Sejarah Melayu tercipta beriringan dengan tumbuhnya gairah membangun arsitektur bermasyarakat dan berbudaya. Nomenklatur tersebut menjadi cetak biru bagi langkah mereka menembus pusaran zaman, sehingga mampu berakselerasi dengan bangsa lainnya. Bentangan alam maritim menjadi saksi bisu dari pergaulan antarkomunitas pulau yang memperkaya satu sama lain. Lokal jenius yang mereka miliki menjadi saringan dalam menerima pelbagai unsur baru yang kemudian datang dan berkembang di pemukiman orang Melayu.

Laut yang terbentang memanjang di antara Sumatra dan Semenanjung Melayu sejak dahulu kala termashur sebagai pentas serba benua yang menjanjikan keramaian dan kesemarakan. Perdagangan yang terpintal memanjang di atasnya, menjadi penghubung utama yang mempertemukan orang Melayu dengan orang asing dari Atas Angin. Diawali tawar menawar harga, komunikasi mereka mulai meluruh dan merembes ke ranah filosofis, hingga terbawa ke alam transendental. Menyeruaknya Islamisasi serta dilanjutkan dengan mantapnya emporium-emporium merupakan pengejawantahan dari dialektika Islam dengan komunitas lokal yang terpilin rapat dan tepat hingga mampu melaju di atas samudra zaman.
Bembicara tenteng relasi kebuadaayan Arab- Melayu tidak bisa lepas dari rangkaian Islamisasi, dalam artian tidak lengkap rasanya jika tidak menyinggung kontribusi bangsa Arab. Dari manusia padang pasir inilah Islam merimbun dan menyemak di lingkungan Melayu. Kegersangan alam tempat tinggalnya, tidak mempengaruhi kehalusan sikap dan keramahan bertutur sehingga mampu meyakinkan penduduk kepulauan untuk beragama Tauhid. Dari mereka entitas kemelayuan sampai pada maturitas, hingga dapat bersinergi dengan komunitas global. Sinergi dagang-dakwah bukan lagi menyinggung masalah perniagaan, selanjutnya telah membawa pada fenomena menyejarah yakni percampuran budaya keduanya.

Baik orang Arab maupun Melayu memiliki keterikatan kultural yang tidak bisa dilepaskan. Kedua etnis ini menjadikan Asia Tenggara sebagai wahana tampilnya peradaban Islam yang berwajah lain dari negeri asalnya. Di kawasan regional tersebut, Islam bersarang dan menerang hingga sinarnya mampu dirasakan hingga masa kini. Budaya yang terbangun, menjadi simpul pemersatu yang menampilkan kehalusan dan keterbukaan yang terjaga di waktu yang lama. Makalah ini akan mengupas masalah bagaimana akluturasi Arab-Melayu terjadi dan berdialektika.

\section{B. Pembahasan}

\section{Orang Arab Menyambangi Nusantara}

Masyarakat Nusantara terbentuk dari gugusan-gugusan pulau yang kemudian diikat oleh suatu kepentingan bersama, yakni pemenuhan kebutuhan pribadinya. Awalnya, mereka saling terkucil satu dengan lainnya, oleh karena segala kebutuhan yang dibutuhkannya telah tersedia di sekitar lingkungannya. Namun, seiring berjalannya waktu, mereka mulai membutuhkan sesuatu yang kemudian langka atau tidak di temukan di sekitar tempat tinggalnya. Ini yang kemudian menyebabkan mereka keluar 
dari kelompoknya, dan mencari hingga mendapatkan kebutuhan tersebut.

Dalam pencariannya mereka mulai bertemu dengan kelompok-kelompok lain yang tak jarang memiliki adat serta tradisi yang berbeda dengan mereka. Perlahan, mereka mulai menjalin komunikasi, lantas dari situ mereka mulai mampu mendapatkan sesuatu yang tidak mereka dapatkan sebelumnya. Pola-pola seperti ini kemudian meluas, hingga tidak lagi terpisahkan oleh jarak serta kontur geografis yang kerapkali merintanginya. Dari sini mulai terbentuk jejaring rute perjalanan manusia dari yang sebelumnya tertapak di darat lalu kemudian mulai melebar hingga membentuk interaksi antar pulau dan benua.

Begitulah kiranya gambaran terbentuknya peta pergerakan manusia. Diawali dari kegiatan berburu dan meramu mereka mulai menyebar hingga sampai ke tanah-tanah yang belum dipijak. Pengembaraan mereka mengindikasikan perkembangan pola pikir dari yang semula hanya mencari makan, perlahan berkembang hingga membentuk masyarakat sistemik (kerajaan).

Entitas masyarakat Asia Tenggara, sejak masa prasejarah telah terbentuk dari pergaulan manusia lintas benua. Mereka bukanlah kelompok yang hanya tahu pemenuhan kebutuhan hidup semata, namun sudah sampai pada manusia berbudaya. Dengan begitu sampainya mereka ke kepulauan Nusantara telah membawa tradisi dari daerah asalnya. Mereka inilah yang kemudian dikatakan sebagai penduduk pribumi Asia Tenggara.

Dinamika manusia Nusantara, tidaklah berhenti sampai disitu. Belakangan, bangsa-bangsa lain mulai berdatangan ke wilayah ini. Bangsa Cina dan India, merupakan sekian dari beberapa orang asing yang datang dan menjalin relasi dengan penduduk pribumi. Sebelumnya, Cina terlebih dahulu menjalin komunikasi dengan masyarakat Asia Barat dalam hal perdagangan. Di antara komoditi unggulan yang laku keras di pasaran Cina dan kala itu hanya dapat ditemui di Asia Barat adalah parfum.

Oleh sebab itu, ketika pedagang Cina mengadakan penjajakan dagang dengan penduduk Nusantara, mereka mulai berpikir komoditi apa yang dapat diniagakan, yang menyaingi komoditi Asia Barat. Setelah dilakukan observasi sederhana di hutan serta lingkungan mereka, barulah penduduk Nusantara dapat memasok kebutuhan yang sebelumnya tidak ditemukan orang Cina di Asia Barat. Beberapa komoditi itu diantaranya adalah kayu cendana, kemenyan dan kapur barus. Ketika perniagaan mulai mapan, barulah dikenalkan rempah-rempah ke pusat-pusat grosir Cina yang langsung menjadi primadona dan dicari banyak orang. ${ }^{1}$

$$
\text { Uraian tersebut seakan }
$$

membenarkan apa yang diungkapkan oleh O.W. Wolters, yang memberitakan tentang perdagangan trans-Asia sebelum abad ke 7 $\mathrm{M}$, yang menjadi latar belakang perkembangan niaga Nusantara awal. Disadari, sarjana Indonesia sebelumnya kerapkali kesulitan menemukan sumber sahih yang membabarkan hubungan niaga yang terjalin sejak abad 5 dan 7 antara Cina dan Asia Barat. Namun hal ini sedikit terjembatani, kendati belum menjawabnya secara lengkap dan komprehensif. Asia Barat yang dimaksud adalah Semenanjung Arab, Persia dan Pakistan Barat yang kala itu sudah berada dalam kekuasaan orangorang Sassania (Arab). ${ }^{2}$

India banyak mengimpor kayukayuan dan rampah-rempah dari Asia Tenggara. Di dalam naskah-naskah India disebutkan bahwa kayu gaharu dan cendana merupakan dua jenis kayu yang didatangkan dari Nusantara. Disamping kayu, rempah-rempah juga menjadi

\footnotetext{
${ }^{1}$ Tim Penulis PUSPINDO, Sejarah Pelayaran Niaga di Indonesia Jilid II (Jakarta: Yayasan Pusat Studi Pelayaran Niaga di Indonesia, 1990) hlm. 12 - 14.

${ }^{2}$ O.W. Wolters, Kemaharajaan Maritim Sriwijaya di Perniagaan Dunia Abad III - Abad IV, Terj. Edy Sembodo (Depok: Komunitas Bambu, 2011) hlm. 13 .
} 
sasaran borongan ketika para pedagang India bertandang ke pasar-pasar Nusantara. Cengkeh dan lada menjadi buah tangan yang harus didapatkan di pasar itu selain pula kapur barus. ${ }^{3}$

Cengkeh yang merupakan rempah yang banyak ditemukan di kawasan Nusantara Timur sudah dikenal lama dalam tradisi India. Tertulis dalam Raghuvamsa karangan Kalidasa (hidup sekitar abad 400 M) cengkeh disebut dengan lavangsa yang berarti cengkeh yang berasal dari Dvipantara. Informasi tempat ini merupakan nama lain dari Nusantara. Oleh orang India, cengkeh digunakan sebagai campuran obat yang diperkenalkan oleh Caraka, tabib di kerajaan Kaniska pada sekitar abad 1 atau $2 .^{4}$

Selain India dan Cina, Pedagang Arab belakangan menjadi aktor penting dalam pergaulan antarbangsa di Asia Tenggara. Etnis Arab yang datang mengalami pembiasan identitas, ada yang mengatakan Arab berarti Yaman, Mekkah, Persia, namun ada pula yang beranggapan pedagang India juga banyak pula yang beretnis Arab. Perbedaan tersebut ditetapkan dari bandar awal mereka berlabuh ke Nusantara. Orang Arab, selain dikenal sebagai saudagar juga tersohor sebagai para ahli agama yang diketahui menyebarkan Islam ke Nusantara.

Mengkaji tentang kedatangan Islam di Nusantara memang tidak cukup diselesaikan pembahasannya hanya satu malam. Banyak pandangan dan banyak teori yang beredar terkait kapan dan siapa yag membawa Islam di gugusan kepulauan ini. Merujuk pada uraian Uka Tjandrasasmita, sumber sejarah yang hingga masa modern sering dihubungkan dengan lawatan orang-orang Muslim ke Indonesia yaitu berita Cina yang berasal dari hikayat Dinasti T'ang. Sumber ini mengisahkan tentang orang-orang Ta-shih (Tazi, Dazi) yang menahan hasratnya

\footnotetext{
${ }^{3}$ Puspindo, Sejarah Pelayaran ..., hlm. 11.

${ }^{4}$ Wolters, Kemaharajaan Maritim ..., hlm. 63-64.
}

menyerang kerajaan Ho-ling yang diperintah oleh ratu Sima sekitar tahun 674 M.

Berlandaskan penafsiran beberapa pakar bahwa orang-orang Ta-shih ialah orang Arab yang diperkirakan kala itu sudah bermukim di sekitar pesisir barat Sumatra. Penyebutan Ta-shih atau Dazi ini adalah sebutan orang Cina bagi orang Arab. ${ }^{5}$ Dari catatan ini, demikian Uka, maka timbullah anggapan bahwa pada abad ke 7 Masehi atau abad pertama Hijriah, orang-orang Muslim telah datang dan mendirikan perkampungan di Nusantara. Dengan begitu, dapat dikatakan pula orang-orang Arab yang membawa Islam dari negeri asalnya.

Sebenarnya, polemik kedatangan Islam bukan hanya didominasi oleh padangan yang mengedepankan orang Arab sebagai pendakwahnya. Di samping mereka, masih terdapat etnis lain seperti India, Benggal, China, Persia. ${ }^{7}$ Tulisan ini tidak mengupas lebih jauh mengenai jejak rekam dakwah mereka di Tanah Air. Hal ini juga bukan berarti pula penulis mengamini suatu teori, melainkan sematamata hanya akan memfokuskan suatu pandangan dengan tema yang diangkat. Jika merunut dinamikanya, teori Arab dalam islamisasi Nusantara, telah melalui uji kelayakan serta menempuh masa verifikasi yang lama.

Azyumardi Azra mengungkapkan bahwa koneksi Nusantara dengan Timur Tengah terhitung sejak penyebaran Islam, dimulai sejak abad ke-8 sampai abad 15.

5 W.P. Groneveldt, Nusantara dalam Catatan Tionghoa, Terj. Gatot Triwira (Depok: Komunitas Bambu, 2009) hlm. 21.

6 Uka Tjandrasasmita, Pertumbuhan dan Perkembangan Kota-Kota Muslim di Indonesia Dari Abad XIII sampai XVIII Masehi (Kudus: Penerbit Menara Kudus, 2000) hlm. 15.

7 Drewes, "New Light of Coming of Islam to Indonesia", BKI (Bijdragen tot de Taal, Land-en Volkenkunde), 124, (1968), hlm. 444-445; Azyumardi Azra, (Ed), Perspektif Islam di Asia Tenggara (Jakarta: Yayasan Obor Indonesia) hlm. xii-xiii.; Slamet Mulyana, Runtuhnya Kerajaan Hindu-Jawa dan Timbulnya Negara-Negara Islam di Nusantara (Yogyakarta: LKiS, 2009). 
Dalam rentang waktu tersebut, setidaknya dapat dipisahkan dalam dua fase. Fase pertama dari komunikasi antarbangsa itu hanyalah terbentuk ketika berada dalam kegiatan berniaga. Kedatangan orang Muslim di Nusantara, terutama Arab dan Persia,menunjukkan bahwa kalangan pendatanglah yang memiliki inisiatif terlebih dahulu untuk berkomunikasi dengan penduduk Nusantara.

Menginjak abad ke 13 M sampai $15 \mathrm{M}$, terjadi perubahan pola relasi yang lebih kompleks yang sekaligus mengawali fase kedua. Jika sebelumnya, dialog baru tercipta di lingkungan penjual dan pembeli, di era ini datangnya Muslim Arab dan Persia, telah mulai mengenalkan Islam dan mengintensifkan syiarnya ke seantero Nusantara. Kunjungan ke ranah Kepulauan ini juga bukan lagi didominasi oleh para pedagang, melainkan ada pula yang memang berprofesi sebagai pengembara dan sufi. Semaraknya kaum ekpatriat ini membuat Islam semakin dikenal di ruang publik hingga kemudian mampu bersinergi dengan kultur setempat. ${ }^{8}$

Selain catatan Cina di atas, terdapat pula catatan lain yang hingga kini masih dianggap reperesentatif sebagai bukti keberadaan orang Arab di Nusantara. Adalah Ibnu Battuta, seorang pengembara Muslim asal Maroko, yang sempat mengunjungi Kepulauan ini tepatnya di kawasan Samudra (Sumatera) pada abad 14. Dalam perjalanannya menuju Cina, ia sempat bermukim selama 2 minggu di kerajaan Samudra Pasai yang kala itu diperintah oleh Sultan Malikuzzahir. Disana ia begitu dimulyakan dan dalam suatu kesempatan, demikian diakui Ibnu Batutta, ia terlibat dikusi serius dengan Sang Sultan. Selama disana, ia bahkan sempat mengenakan baju khas setempat, yang sepertinya merupakan wujud penghormatan untuk tuan rumah. ${ }^{9}$

8 Azyumardi Azra, Jaringan Ulama (Jakarta: Kencana, 2007), hlm. 57.

${ }^{9}$ Ross E. Dunn, Petualangan Ibnu Batutta Seorang Musafir Muslim Abad 14, terj. Amir Sutaarga
Selain adanya catatan Ibnu Batutta, keberadaan para pedagang Arab juga disebutkan oleh Marco Polo yang mengunjungi Nusantara tepatnya di Perlak dan beberapa bandar di Sumatra lainnya, seabad kemudian setelah Ibnu Batutta. Ia mengungkapkan: ${ }^{10}$

We shall begin with the
kingdom of Felech, which is
one of the eight. Its inhabitants
are for the most part idolaters,
but many of those who dwell in
the seaport towns have been
converted to the religion of
Mahomet, by the Saracen
merchants who constantly
frequent them.

( ... dimulai dari kerjaaan

Felech (Perlak), satu dari delapan kerajaan (yang dikunjungi Marco Polo). Banyak dari rakyatnyanya sebelumnya adalah penyembah berhala dan sebagian besar yang tinggal di kawasan pelabuhan telah menganut agama Muhammad sebab diajak oleh para pedagang Arab yang sering mengunjungi mereka).

Dua catatan perjalanan di atas cukup menjadi bukti meyakinkan, bahwa Islamisasi di Nusantara dimotori oleh orang Arab. Namun, hal ini bukanlah suatu finalitas, karena akan banyak sejarawan dan pengamat yang mendebatnya. Mereka menggunakan serangkaian alibi yang di satu pihak ada yang mengafirmasi dan dipihak lain ada yang memandangnya dengan kritis.

Salah satu ilmuwan yang kritis memandang islamisasi berasal dari Tanah Arab adalah R.A. Kern, dalam bukunya yang berjudul Islam in Indonesie. Bahkan, Snouck Hurgronje, orientalis sekaligus

(Jakarta: Yayasan Obor Indonesia, 2011) hlm. 291291.

10 Manuel Komroff, ed, The Travel of Marco Polo The Venetian (New York: W.W. Norton, 1930) hlm. 155. 
sosok yang berperan dalam mencipta dinamika Islam Nusantara abad 19. Ia mengatakan bahwa, kebanyakan mereka yang meyakini orang Arab sebagai penyebar benih Islam, mendasarkan pada catatan-catatan kuno mengenai Nusantara yang berbahasa Arab yang memberitakan bahwa pada abad 9, para pelaut Arab telah mendengar tentang Jawa dan Sumatra dan besar kemungkinan mereka telah mendatangi dua pulau tersebut. Sumber ini diperkuat dengan semakin mengkristalnya legenda yang mendukung bahwa para Wali (Wali Songo ?) yang dianggap menyebarkan Islam di Jawa kebanyakan orang Arab.

Memang benar, demikian Snouck, informasi berbahasa Arab ini banyak mengupas mengenai Jawa dan Sumatra, namun pemetaan lokasi-lokasinya tidaklah akurat dan jenis uraiannya tergolong sebagai dongeng para pelaut. Tidak satupun dari informasi tersebut adalah hasil tinjauan langsung ke lapangan. Hasil pengamatan Ibnu Batutta di Sumatra merupakan suatu kebetulan dan ia sama sekali tidak melaporkan adanya pemukiman Arab disana. Snouck baru meyakini adanya hubungan orang Arab dengan orang-orang Hindia Timur terjadi sejak abad XVII, yakni ketika Mataram dan Banten meminta legitimasi gelar sultan dari Syarif Mekkah.

Snouck lebih meyakini bahwa Islam masuk ke Nusantara melalui India. Namun, itu hanya sebatas ketetapan dari segi keberangkatannya saja. Para pendakwah yang datang dari India itu umumnya adalah orang Arab dan Persia yang ikut pula membawa tradisi masingmasing ke tanah-tanah Kepulauan ini. dengan begitu, ajaran Islam yang sampai di Indonesia bukanlah murni sebagaimana yang diajarkan ulama asal Haramain, melainkan telah mengalami percampuran dengan tradisi India yang telah berdialektika dengan lingkungan setempat. Snouck menganggap bahwa pengkultusan wali yang masih hidup atau yang sudah mati adalah sebagian dari kekayaan tradisi
Islam Nusantara adalah salah satu kebiasaan yang ditemukan di Hindustan, pembentukan pelbagai sekte, ajarah mistisisme panteis serta banyak lagi produk keislaman lainnya tidak pernah hidup dan berkembang di Tanah Arab. ${ }^{11}$

Snouck mencatat bahwa terjadi renovasi pergaulan antarbangsa yang besar menginjak masa ketika orang-orang Eropa masuk ke Nusantara pada abad 16. Modernisasi navigasi dan pelayaran yang dimiliki bangsa Eropa perlahan menyisihkan orang India dari Nusantara. Hal ini menjadi permulaan semakin luasnya sebaran pengaruh Arab di gugus kepulauan ini. Sebelumnya, orang India dan Arab seringkali terlibat dalam relasi yang sulit, namun perlahan mencair akibat perdagangan antara keduanya. Lalu berlanjut pula pada meratanya Islam di India. Perdagangan ini pula yang kemudian melapangkan orang-orang Arab dari Hadramaut dan Mekkah banyak berdatangan ke Nusantara hingga tiga abad setelahnya.

Orang Arab asal Hadramaut selanjutnya disebut orang Arab Hadrami memiliki bentangan sejarah tersendiri yang panjang di Nusantara. Kondisi geografis yang keras, memaksa mereka untuk berdiaspora guna mencari kehidupan yang lebih baik. Sebagian dari mereka ada yang menuju Hindustan dan mulai menemukan kehidupan yang layak. Ketika datang informasi mengenai Nusantara, sebagian dari mereka ada yang tergerak untuk berspekulasi mencari peruntugan berbekal pengetahuan dan keterampilan khusus yang mereka miliki ke daerah Kepulauan tersebut.

Snouck memandang khususnya di luar Jawa, yang tidak berada dalam kuasa dinasti pribumi yang cukup kuat memepengaruhi aktivitas mereka, banyak orang Arab yang mewarnai gelaran dinamika Islam sejak abad 17. Sebagian dari mereka ada yang berhasil medirikan

${ }^{11}$ C. Snouck Hurgronje, Kumpulan Karangan Snouck Hurgronje IX, Terj. Sutan Maimun dkk (Jakarta: INIS, 1994) hlm. 95-97. 
kerajaan pribumi, seperti Kesultanan Pontianak di Kalimantan dan Kesultanan Siak di pesisir Sumatra Timur. Di belahan Nusantara lainnya, beberapa dari mereka ada yang dipercaya menduduki jabatanjabatan penting dalam pemerintahan lokal dan memiliki keududukan dan pengaruh yang kuat. Mereka tidak begitu saja dibutakan dengan jabatan hingga hanya mengeruk keuntungan pribadi namun ikut pula merenovasi arstektur keislaman pribumi sesuai dengan tradisi Arab. Habib Abdurrahman az-Zahir merupakan suatu contoh yang tepat. Ia menjadi pejabat penting di kerajaan Aceh abad 19, sekaligus salah satu panglima perang dalam Perang Aceh.

Di samping itu, masih terdapat nama Abdudllah bin Abdul Kadir Munsyi, seorang peranakan Arab-India yang menjadi duta bagi raja-raja muda Malaka yang hidup sekitar abad 19. Abdullah diserahi tugas menjalin komunikasi lintas kerajaan kecil di Semenanjung Malaya serta ke beberapa daerah Melayu Serumpun lain seperti Riau, Lingga, Pahang, Trengganu dan Kelantan. Seperti az-Zahir, Ia merupakan prototipe seorang Arab yang pandai berdiplomasi sehingga pihak kerajaan tak ragu menggunakan jasanya. $^{12}$

Kebanyakan orang-orang Arab yang ada di Nusantara berkecimpung dalam perniagaan. Sebagian dari mereka hidup mengelompok dengan sesamanya dalam suatu komunitas. Di kota-kota pelabuhan besar Jawa mereka biasanya tinggal di pekojan, suatu nama yang berarti pula pemukiman orang-orang Koja, yakni adalah pedagang dari India. Belakangan diketahui, pemerintah Belanda mengadakan pembatasan untuk menekan

12 G.W.J. Drewes, "Pemahaman Baru tentang Kedatangan Islam di Indonesia ?" dalam Ahmad Ibrahim dkk, peny, Islam di Asia Tenggara Perspektif Sejarah, Terj. A Setiawan Abadi (Jakarta: LP3ES, 1989) hlm. 21-22. jumlah kedatangan orang Arab yang semakin membengkak setiap tahunnya. ${ }^{13}$ Apa yang disampaikan oleh Snouck sebelumnya, merupakan satu diantara kumparan-kumparan gagasan lain tentang Islamisasi Nusantara. Ketika menyimaknya, tentu sudut pandang ilmiah $a$ la Snouck yang dikedepankan. Menyebarnya komunitas Arab, demikian Snouck, dipengaruhi pula oleh keberadaan kekuatan kolonial Belanda di gugus negeri ini. Jikapun begitu hendaknya jangan cepat puas dengan pendapat ini, mengingat tentu uraian tersebut, pantas dikaji ulang.

Datang dan berkembangnya Islam telah menguat beberapa abad sebelum kolonialisme Nusantara tercipta. Menyikapi hal ini, agaknya perlu diperhatikan apa yang diungkapkan $\mathrm{M}$. Naquib al-Attas bahwa dalam beberapa segi, kehadiran imperialisme dan kebudayaan Barat pada abad 16 dan 17, berimplikasi pada lambatnya proses sejarah pengislaman. ${ }^{14}$

Para pedagang Arab dikenal sebagai sosok tangguh di laut sehingga tidak heran mereka dapat berdiam menyesuaikan dengan lingkungan yang berbeda dengan yang ada di tanah asalnya. Uka Tjandrasasmita mengutip Rita R. Di Meglio menyebutkan bahwa sebelum abad 9 dan 11, perkampungan Arab sudah baru terdapat di Kalah, Takuapa, Qaqullah dan Lambri (Aceh). Dalam suatu sumber Cina diberitakan pula bahwa orang Arab telah banyak yang bermukim di beberapa pelabuhan India. Selain itu, berita dari penulis-penulis Arab dan para geografer abad 9 dan 11 banyak yang menceritakan Nusantara dan Semenanjung Melayu, sesuatu yang menunjukkan mereka telah mengenal dan memandang wacana Asia Tenggara masa lalu sebagai sajian yang penting dalam karyanya. Ketika islamisasi berada pada era keemasannya, para

${ }^{13}$ Snouck Hurgronje, Kumpulan Karangan ..., hlm. 99-100.

14 Syed Muhammad Naquib al-Attas, Islam dalam Sejarah Kebudayaan Melayu (Bandung: Mizan, 1990) hlm. 43. 
pedagang Arab tinggal dalam perkampungan khusus di Banten, Aceh dan lain-lain. Di masa-masa awal, orang Arab banyak yang beradagang pakaian sedangkan saudagar Persia menjajakan obat-obatan. $^{15}$

Menurut L.W.C. Van den Berg, sebelum diadakan pencatatan jumlah orang Arab di Nusantara yang baru terjadi pada abad 19, diketahui mereka banyak tinggal di Aceh. Dari sini, kemudian sebagian ada yang hijrah ke Pontianak dan Palembang. Menginjak tahun 1820 orang-orang Arab mulai banyak menetap di Jawa dan kolonikoloni mereka baru bermukim di kawasan Nusantara timur pada 1870. Penguasaan Inggris atas Singapura berdampak positif bagi perkembangan perdagangan wilayah sekitar. Setelah 15 tahun berselang, Singapura menggantikan posisi Aceh sebagai bandar pemberhentian jalur kapal uap Arab-Nusantara. ${ }^{16}$

\section{Hidup di Bumi Melayu}

Tersebarnya koloni Arab di persada Nusantara, telah ikut pula mewarnai konstruksi ruang publik setempat. Beberapa dari mereka bukan lagi datang dan beraktivitas sebagai pedagang, melainkan telah memainkan peran penting dalam sendi kehidupan masyarakat lainnya. Diantara mereka ada yang berprofesi sebagai negarawan, ulama, sastrawan dan lain-lain. Bahkan di Singapura abad 19, ada orang Arab yang bergerak di bidang usaha penampungan bagi pendatang baru dan jika perlu menyediakan sarana melanjutkan perjalanan, dengan syarat di kemudian hari biaya penginapan dan uang muka dikembalikan beserta bunganya.

Selain hidup dalam komunitasnya, di antara mereka ada pula yang hidup berdampingan di lingkungan pribumi. Tidak ada perbedaan status

15 Uka Tjandrasasmita, Kota-Kota Muslim ..., hlm. 148-149.

${ }^{16}$ L.W.C. Van den Berg, Orang Arab di Nusantara, Terj. Rahayu Hidayat (Depok: Komunitas Bambu, 2010) hlm. 110. kemasyarakatan, mereka justru larut dalam pola hidup masyarakat setempat.

Moh. Taib Osman mengakui, di pelataran sosial Melayu, Islam bukan hanya dimaknai sebatas agama, melainkan telah terartikulasi sebagai peradaban Islam Melayu. Terhitung sejak abad 17, telah ada pemukiman-pemukiman permanen yang tersebar di dunia Melayu. Bahkan, mengutip dari Wiiliam R. Roff, dikatakan bahwa lalu lalangnya saudagar, musafir dan cendikiawan agama telah menjadi pemandangan yang lumrah di keseharian hidup orang Melayu.

Ungkapan berbeda diutarakan A.C. Milner yang menyebutkan bahwa pada awal pengenalannya, Islam tidak langsung diterima oleh para raja Melayu. Meskipun diketahui orang-orang Arab banyak mengunjungi kawasan Melayu, namun pembicaraan mengenai agama bukanlah menjadi pokok tema yang dikedepankan. Kala itu, raja Melayu masih banyak menganut kepercayaan yang sejak lama telah mentradisi seperti ajaran Budha Bodihisatva. Meskipun begitu, raja Melayu menunjukkan empati yang besar ketika menerima dengan baik kedatangan orang Arab. Setelah beberapa waktu, barulah mereka sedikit demi sedikit mengambil ajaran dari doktrin-doktrin Islam abad pertengahan.

Masuknya pemahaman Islam dalam perilaku istana Melayu, serta merta tidak merubah tatanan kepemimpinan Melayu yang sudah dibangun berbasiskan tradisi setempat. Unsur keislaman sifatnya hanya memperkaya. Dengan semakin banyaknya saudagar Muslim yang mendominasi perdagangan kawasan Melayu, membuat para raja serasa"dituntut" untuk menjelaskan fungsifungsinya kepada para rakyat barunya yang berasal dari negeri padang pasir itu. Masuknya para raja Melayu dalam Islam boleh dikatakan awalnya hanya bersifat pragmatis, mengingat dunia Islam di Atas Angin sana dipahami oleh raja-raja Melayu sebagai kawasan peradaban yang lebih besar dan beradab dari yang selama 
ini diketahuinya, di samping haluan ekonomi lokal yang telah dikuasai orang Arab. ${ }^{17}$

Di Filipina, yang di beberapa pulaunya notebene masih termasuk dunia Melayu, termasuk pula di pulau-pulau Melayu lainnya, status "Sayid" amat dihormati penduduk lokal. Status istimewa tersebut memungkinkan sebagian orang mendirikan kerajaan bagi diri mereka sendiri dan menyelenggarakan kepemimpinan di lingkungan-lingkungan orang Melayu. Sebagai keturunan Nabi, demikian yang disampaikannya ketika berkenalan dengan penduduk lokal, mereka tidak saja dianggap mempunyai karisma namun juga kesalehan dan pemahaman agama yang mendalam. Dalam pergaulannya di seantero Melayu Serantau, orang Arab dipercaya menjadi penasehat pemerintahan dan tak jarang saran mereka amat didengar sehingga ikut pula membawanya dalam percaturan istana tingkat atas. ${ }^{18}$

Taib Osman menambahkan, jika orang India dan Persia bertanggungjawab menyebarkan mistisisme, panteisme serta unsur-unsur Islam lainnya, orang-orang Arab justru membawa ortodoksi keagamaan bagi dan memperkenalkannya kepada orang-orang Melayu. Anggapan ini tentu saja tidak belaku bagi orang Arab secara keseluruhan, mengingat ada pula orang Arab yang mempertunjukkan keahlian sihir dan ramalan. Diantara orang Arab ada pula yang menjadi pedagang keliling yang ketika mangkal kerap menjajakan batu-batu semimulia jimat yang mengadung kekuatan tertentu. ${ }^{19}$

Dari potret serbaneka profesi tersebut, dapat disajikan satu gambaran betapa orang Melayu telah menjalin dialog

17 A.C. Milner, "Islam dan Martabat Raja Melayu", Ahmad Ibrahim, Islam di Asia Tenggara ..., hlm. 70-71.

18 Mohd. Taib Osman, "Pengislaman Orang-orang Melayu Suatu Transformasi Budaya" dalam Ahmad Ibrahim, Islam di Asia tenggara ..., hlm. 91-92.

19 Mohd. Taib Osman, "Pengislaman Orang-orang Melayu ...", hlm. 92. yang efektif dengan bangsa Arab. Perjumpaan mereka dengan orang Arab di tengah perjalanan bukan lagi memunculkan pemanadangan "orang pribumi" dan "orang asing" melainkan telah mengharmoni, yang ditandai dengan saling bertegur sapa bahkan tidak jarang terlibat dalam pembicaraan yang serius. ilutrasi demikian bisa diperoleh misalnya manakala terjadi diskusi serius seputar penjualan jimat dan batu mulia terjadi. Seorang pedagang Arab dituntut memiliki pemahaman kognitif serta supranatural kemelayuan yang kuat, jika ingin baranganya ditawar dengan harga tinggi oleh orang Melayu. Di sisi lain, orang Melayu akan terlibat dalam pembicaraan serius ketika akan membeli jimat atau paling tidak terjadi konsultasi intensif antara keduanya, mengingat orang yang datang ke paranormal, biasanya akan menceritakan keluhan hidupnya yang lantas ditanggapi oleh si paranormal.

Di Sumatra, koloni Arab terbesar terdapat di Aceh dan Palembang. Batavia dan Pontianak, merupakan dua kota besar lainnya yang dihuni banyak orang Arab. Di kawasan Melayu, sendiri orang Arab hidup secara berdampingan dengan penduduk lokal dan tidak melakukan komunalisasi seperti yang terjadi di kotakota sebelumnya. Informasi yang bisa ditelisik adalah di Jambi dan Siak, orangorang Arab telah bercampur dengan kehidupan pribumi.

Koloni-koloni Arab yang terdapat di wilayah jajahan Inggris yang tertua terdapat di Malaka. Di sini mereka mengalami kemunduran. Berdirinya Singapura pada 1819, menjadi angin segar bagi mereka. Namun begitu, komunitas Arab yang berdiam di wilayah itu hampir semuanya berdarah campuran dan sebagian besar hidup sederhana. Mereka yang memiliki modal dan tenaga banyak yang pindah ke Singapura.

Di Negeri Singa ini, komunitas Arab mulai berkembang, meskipun tidak menjadi yang terbesar di Nusantara. Pulau yang baru menemukan modernitasnya ini, 
perlahan menjadi tempat persinggahan orang Arab yang akan mencari peruntungan hidup di Timur Jauh. Setiap tahunnya dikabarkan jumlah kedatangannya semakin meningkat. Seperti pula halnya komunitas Arab di Pulau Penang walaupun jumlahnya tidak sebesar di Singapura. Tidak seperti wilayah jajahan Belanda, yang memberlakukan kebijakan bahwa setiap komunitas Arab diwajibkan memiliki kepala koloni, orang-orang Arab di wilayah jajahan Inggris berada langsung dibawah kendali pemerintahan Eropa.

Berikut merupakan tabel sensus orang Arab yang dilakukan oleh pemerintah Hindia Belanda pada 1885. Dalam hal ini, hanya pulau Sumatra dan Kalimantan yang ditampilkan, mengingat di dua pulau tersebut, merupakan wilayah yang banyak didiami orang Melayu yang masih menganut adat tradisi kemelayuan sejak masa leluhurnya.

\begin{tabular}{|c|c|c|c|c|c|c|c|c|c|c|}
\hline \multirow[t]{2}{*}{ Keresidenan } & \multirow[t]{2}{*}{ Kota } & \multicolumn{2}{|c|}{$\begin{array}{l}\text { Arab Lahir } \\
\text { di Arab }\end{array}$} & \multicolumn{3}{|c|}{$\begin{array}{l}\text { Arab Lahir di } \\
\text { Nusantara }\end{array}$} & \multirow[t]{2}{*}{ Jum. } & \multirow{2}{*}{$\begin{array}{l}1885 \\
\text { (jumlah di } \\
\text { setiap } \\
\text { keresidenan) }\end{array}$} & \multirow[t]{2}{*}{1870} & \multirow[t]{2}{*}{1859} \\
\hline & & Pria & Anak & Pria & Wan & Anak & & & & \\
\hline $\begin{array}{l}\text { Pantai Barat } \\
\text { Sumatra }\end{array}$ & $\begin{array}{l}\text { Padang } \\
\text { Benteng van } \\
\text { der Cappelen } \\
\text { Payakumbuh } \\
\text { P. Nias }\end{array}$ & $\begin{array}{l}16 \\
2 \\
2 \\
1\end{array}$ & $\begin{array}{l}- \\
- \\
-\end{array}$ & $\begin{array}{l}23 \\
2 \\
3 \\
13\end{array}$ & $\begin{array}{l}8 \\
1 \\
2 \\
9\end{array}$ & $\begin{array}{l}78 \\
4 \\
9 \\
18\end{array}$ & $\begin{array}{l}125 \\
9 \\
16 \\
41\end{array}$ & 191 & 76 & 26 \\
\hline Bengkulu & Kroe & - & - & 7 & 5 & 4 & 16 & 16 & 6 & 28 \\
\hline Lampung & Teluk Betung & 2 & - & 6 & 1 & 3 & 12 & 12 & 29 & 1 \\
\hline Palembang & $\begin{array}{l}\text { Pelembang } \\
\text { Jambi }\end{array}$ & $\begin{array}{l}61 \\
- \\
\end{array}$ & $\begin{array}{l}- \\
-\end{array}$ & $\begin{array}{l}429 \\
8\end{array}$ & $\begin{array}{l}653 \\
12\end{array}$ & $\begin{array}{l}951 \\
11\end{array}$ & $\begin{array}{l}2094 \\
31\end{array}$ & 2125 & 2043 & 1764 \\
\hline $\begin{array}{l}\text { Pantai } \\
\text { Timur } \\
\text { Sumatra }\end{array}$ & $\begin{array}{l}\text { Siak } \\
\text { Asahan } \\
\text { Deli } \\
\end{array}$ & $\begin{array}{l}20 \\
- \\
8 \\
\end{array}$ & $\begin{array}{l}1 \\
- \\
- \\
\end{array}$ & $\begin{array}{l}61 \\
15 \\
7 \\
\end{array}$ & $\begin{array}{l}69 \\
7 \\
5 \\
\end{array}$ & $\begin{array}{l}77 \\
17 \\
8 \\
\end{array}$ & $\begin{array}{l}228 \\
39 \\
28 \\
\end{array}$ & 295 & $?$ & $?$ \\
\hline Aceh & $\begin{array}{l}\text { Kota Raja } \\
\text { Wilayah } \\
\text { Bawahan } \\
\text { Aceh }\end{array}$ & 12 & - & 27 & 24 & 1218 & 2768 & 2848 & $?$ & $?$ \\
\hline Bangka & Mentok & 10 & - & 44 & 44 & 61 & 159 & 159 & 487 & 54 \\
\hline Belitung & $\begin{array}{l}\text { Tanjung } \\
\text { Pandan }\end{array}$ & - & - & 2 & 1 & 1 & 3 & 3 & $?$ & ? \\
\hline $\begin{array}{l}\text { Pantai Barat } \\
\text { Borneo }\end{array}$ & $\begin{array}{l}\text { Pontianak } \\
\text { Kubu } \\
\text { Sintang } \\
\text { Sambas } \\
\text { Daerah lain }\end{array}$ & $\begin{array}{l}32 \\
- \\
6 \\
1 \\
2\end{array}$ & $\begin{array}{l}- \\
- \\
1 \\
- \\
-\end{array}$ & $\begin{array}{l}506 \\
68 \\
29 \\
15 \\
8\end{array}$ & $\begin{array}{l}487 \\
37 \\
24 \\
20 \\
1\end{array}$ & $\begin{array}{l}536 \\
45 \\
36 \\
51 \\
8 \\
\end{array}$ & $\begin{array}{l}1561 \\
150 \\
96 \\
87 \\
19 \\
\end{array}$ & 1913 & 1222 & 800 \\
\hline $\begin{array}{l}\text { Pantai } \\
\text { Selatan dan } \\
\text { Timur Borneo }\end{array}$ & $\begin{array}{l}\text { Banjarmasin } \\
\text { Pantai Selatan } \\
\text { Pantai Timur }\end{array}$ & $\begin{array}{l}100 \\
- \\
5\end{array}$ & $\begin{array}{l}8 \\
- \\
-\end{array}$ & $\begin{array}{l}95 \\
15 \\
45\end{array}$ & $\begin{array}{l}104 \\
7 \\
18\end{array}$ & $\begin{array}{l}375 \\
19 \\
36\end{array}$ & $\begin{array}{l}682 \\
41 \\
104\end{array}$ & 827 & 542 & $?$ \\
\hline
\end{tabular}

Di Semenanjung Melayu yang merupakan jajahan Inggris sensus pertama orang Arab diadakan pada 1874. Sesus yang terakhir di publikasikan pemerintah kolonial adalah pada 1884.

1874

\begin{tabular}{|l|l|l|l|l|}
\hline Provinsi & Pria & Wanita & Anak & Jumlah \\
\hline Singapura & 189 & 111 & 165 & 465 \\
\hline
\end{tabular}




\begin{tabular}{|l|l|l|l|l|}
\hline Malaka & 81 & 87 & 135 & 303 \\
Penang & 106 & 106 & 110 & 322 \\
Weellesley & 11 & 8 & 13 & 32 \\
\hline Jumlah & 387 & 312 & 423 & 1122 \\
\hline
\end{tabular}

1884

\begin{tabular}{|l|l|l|l|l|}
\hline Provinsi & Pria & Wanita & Anak & Jumlah \\
\hline Singapura & 445 & 166 & 225 & 836 \\
Malaka & 70 & 71 & 86 & 227 \\
Penang & 163 & 158 & 200 & 521 \\
Weellesley & 21 & 14 & 18 & 53 \\
\hline Jumlah & 699 & 409 & 529 & 1637 \\
\hline
\end{tabular}

Bermastautinnya orang-orang Arab di belahan akuatik serta daratan Melayu sedikit banyak membawa pengaruh bagi penduduk lokal. Islamisasi merupakan salah satu pengaruh yang dapat dirasakan hingga sekarang. Pembauran yang terjadi balakangan menyentuh ranah budaya yang memiliki karakter kuat di dunia Melayu. Kelenturan berdialog, membuat Islam dapat diterima sebagai unsur pemerkaya dalam produk-produk budaya Melayu.

\section{Syair dan Musik: Bukti Racikan budaya Arab-Melayu}

Pendekatan budaya, rupanya menjadi alternatif yang menarik dikedepankan ketika membaca gelagat zaman. Munculnya peradaban bukan hanya semata disebabkan oleh peritiwa politik, melainkan juga menyentuh aspek lain, seperti halnya yang terdapat di dunia Melayu. Suatu afirmasi ditunjukkan Walter A. Fairservis Jr. yang mengatakan bahwa seseorang yang akan menulis asalusul dari perubahan kebudayaan dan sifat dari kebudayaan purba - termasuk kebudayaan yang lain - ia harus memastikan jika sumber-sumber yang diambilnya berasal dari sejarah kebudayaan, bukan dari sejarah politik dan sastra, betapapun berharganya fakta-fakta itu. $^{20}$

Terciptanya entitas Melayu yang berbasiskan pada heterogenitas manusia lintas benua, menerbitkan babak baru bagi

20 Walter A. Fairservis Jr., Asal-Usul Peradaban Orang Jawa dan Tiongkok, Terj. Anwar (Surabaya: Selasar Surabaya Publishing, 2009) hlm. 168. peradaban Nusantara. Seiring dengan didapuknya bahasa Melayu sebagai alat komunikasi Nusantara (lingua franca) perlahan turut pula membawa angin segar bagi gairah berbudaya masyarakatnya. Laiknya Hindu dan Budha sebelumnya, ajaran Islam tidak hanya terpaut pada kesadaran kosmik semata, melaikan turut pula mengental dalam realitas sosial, bahkan menjelma menjadi pirantipirantinya.

Malik bin Nabi pernah berujar bahwa unsur kebudayaan terdiri dari empat aspek; 1) dustur (konstitusi); 2) cita rasa keindahan; 3) logika terapan; 4) teknik (menurut istilah Ibnu Khaldun). ${ }^{21}$ Keempat unsur itu kiranya dapat ditemukan di hampir semua bentuk produk kebudayaan. Paling tidak, keindahan - walaupun subjektif sifatya - menjadi nuansa umum yang tercitra darinya. Suatu ajaran etis tentu menjadi lebih berkesan jika disulam dengan tembang maupun diukir lewat kayu atau disulam lewat kain. Dari keindahan muncul pemikiran yang bersumber dari logika. Hal ini rupanya yang membentuk seperangkat teknik kultural untuk memaknainya.

Membincang terciptanya masyarakat, maka tidak akan lepas dari tema-tema sentral yang membentuknya. Satu diantara tema tersebut adalah aspek kebudayaan. Kebudayaan bukanlah suatu produk manusia yang dapat ditelisik hanya

${ }^{21}$ Malik bin Nabi, Membangun Dunia Baru Islam, Terj. Afif Muhammad dkk (Bandung: Mizan, 1995) cet. 2 , hlm. 98 . 
dengan satu sudut pandang, melainkan merangkum pula pandangan lain yang saling memperkaya. Wilayah ini merupakan suatu sakralitas yang terus dipelihara, mengingat muatan emik yang dikandungnya. Keindahan dan norma hidup merupakan dua diantara manfaat yang diunduh dari suatu produk budaya. Betapa tumpulnya kejiwaan manusia tanpa kebudayaan, serasa merasa namun tidak berasa.

Generasi kekinian patut memuji sekalian leluhur, mengingat dimensi kemelayuan nyatanya memiliki sungaisungai budaya yang tidak terkira jumlahnya. Dalam kehidupan masa kini, hampir setiap budaya Melayu dapat ditemukan bahkan semakin mengembang. Adat dan tradisi Melayu menjadi suntikan gairah dalam tampilan bermasyarakat dan bernegara. Kebekuan berkata dan berpikir, seorang luruh dan terlupa, manakala menyaksikan keelokan serta kesyahduan dendang Melayu. Penikmatnya serasa diajak ke taman surgawi nan elok. Pun dengan tetariannya, berdaya pikat magis, rancak diiringi kendangan yang ramai.

$$
\text { Melayu pra-Islam sebenarnya }
$$

sudah disesaki oleh lantunan syair tradisional yang terendam dalam bentuk mantra-mantra. Ciri yang paling menonjol adalah isinya yang masih animistik, yakni berisi pemujaan atas kayu, laut, sungai , hutan, gunung, hewan dan lain-lain yang dipercaya memberikan kekuatan tertentu bagi perapalnya. Ketika Islam masuk, tradisi merapal mantra perlahan mendapatkan pengaruh, yakni seperti menyertakan kalimat bismillahirrahmanirrahim atau laa ilaha illallah dalam komposisinya. Di samping itu, beberapa tokoh penting seperti Nabi Muhammad, Nabi Sulaiman dan Nabi Khidir menggantikan kedudukan benda dan makhluk animistik yang diyakini menjadi sarana keberhasilan suatu mantra. Penggunaannya pun mulai disesuaikan dengan ajaran Islam.

Selain itu, masih terdapat beberapa produk budaya lain, hasil pernikahan budaya Arab dengan Melayu, antara lain seperti: zikir, barzanji, marhaban, rodat, ratib, hadrah, nasyid, irama padang pasir, dan lain sebagainya. Alat musik yang digunakannya pun amat khas dengan perpaduan Islam seperti: rebab, biola (dari Barat), gendang nobat, nafiri, serunai, gambus, 'ud dan lain-lain.

Belakangan, konsep musik Islam yang hidup di Tanah Arab, ikut pula merasuk dalam pergaulan kawasan ini. Terlebih paradigma lokal yang mengatakan adat bersendi syara', syara' bersendi kitabullah seakan menjadi legitim bagi perluasan pengaruh tersebut. Di wilayah Timur Tengah dan sekitarnya, konsep-kosep dimensi ruang (modus) dalam musik, mengenal istilah maqam di Turki, datsgah di Persia, naghamah di Mesir, dan taba di Afrika Selatan.

Selain itu, terdapat pula ide ritme yang dikenal dengan iqaat di Arab Timur, durub di Turki dan mazim di Maghribi. Di masa sekarang, dapat pula disaksikan penyerapan unsur musik Islam dalam bentuk gaya-gaya ritmik yang tidak terikat dalam metrum, biasanya banyak ditemukan dalam melodi-melodi pembuka musik Islam seperti zapin dan nasyid. Dalam permusikan Islam, teknik ini disebut dengan avaz atau taqsim. ${ }^{22}$

Dalam ranah seni tari, Islam juga memberikan semburat warna, salah satunya adalah tari zapin. Zapin sendiri merupakan tari yang menampilkan serangkum gerak gemulai kaya makna. Beberapa diantaranya membentuk gerak sembah atau salam, gerak ragam-ragam (langkah belakang, siku keluang), anak ayam, anak ikan, buang anak, lompat kecil, lompat tiung, pisau belanak, pecah, tahto, tahtim dan lain-lainnya. Begitu pula dalam seni hadroh, terdapat aneka gerak seperti gerak-gerak selepoh, senandung, ayun, sembah dan lainnya.

Sebagian yang lain, mengandung muatan sufisme yang berpadu dengan

\footnotetext{
${ }^{22}$ Muhammad Takari, Zapin Melayu dalam Peradaban Islam, (artikel) hlm. 9.
} 
kekhasan Melayu. Pelbagai gerak menyerupai huruf alif, mim atau $b a$, merupakan sebagian dari pengejawantahan sufiisme dalam koreografi Melayu. Langgam tari jenis ini merupakan salah satu bukti lain, bahwa kontinuitas tradisi Melayu senantiasa bersinggungan dengan unsur di luar dirinya.

Pada dasarnya, setiap lagu dan tari Melayu berasaskan pada ajaran-ajaran Islam. Dalam upaya mencipta suatu kesenian, orang Melayu senantiasa tidak lupa untuk menginternalisasi paradigma adat yang disandingkan pada korpus agama. Dengan kata lain, bila adat atau budaya berseberangan dengan syara', maka produk itu hendaknya disesuaikan terlebih dahulu dengan nafas keislaman, bukan sebaliknya. Budaya sudah selaiknya berada dalam komando agama. ${ }^{23}$

Syair, musik dan tari Arab-Melayu, belakangan semakin berimprovisasi menjadi suatu bentuk budaya yang laris manis di tengah masyarakat. Walaupun pengaruh Arab amat mencolok, namun ketika telah berdialektika dengan tradisi Melayu, wajah Arab bukan lagi identik dengan seni padang pasir, namun telah berubah menjadi kreasi baru yang berbeda dengan di negeri ibunya. Dendang syair Melayu belakangan semakin banyak memperoleh pengaruh dan menjadi suatu seni suara yang berpadu dengan musik yang rancak. Satu diantara yang mewarnai arsitektur Tanah Air adalah musik dangdut.

Dangdut merupakan suatu produk musik yang DNA-nya berasal dari seni musik Melayu. Kendati semakin ke belakang, syair-syair atau komposisi maknanya semakin berkembang mengikuti zaman, bahkan terkesan out of box, namun tetap memiliki suatu identitas yang menunjukkan kekhasan serta kaitanya dengan musik Melayu. Kepopulerannya amatlah tinggi, bahkan boleh dikatakan seni musik ini merupakan produk budaya Melayu tersukses sepanjang masa, selain

\footnotetext{
${ }^{23}$ Muhammad Takari, Zapin Melayu ..., hlm. 9.
}

pendakuan bahasa Melayu sebagai bahasa Indonesia.

Moh. Muttakin menjelaskan bahwa Dangdut pertama kali muncul pada tahun 1970-an. Awalnya, perkataan "dangdut" merupakan ejekan bagi salah satu corak musik Melayu yang tengah berkembang pada masa itu. Dalam hubungannya sebagai jenis musik, istilah dangdut merujuk pada bunyi sepasang gendang yang dimainkan dengan teknik glissando yang kemudian menimbulkan bunyi "dang" dan "dut". Seiring berjalannya waktu, corak musik yang didominasi oleh gendang ini dinamakan dangdut.

Dalam menelisik sejarah musik dangdut, agaknya perlu flashback sejenak guna mengetahui bagaimana genre ini terbentuk. Irama Melayu yang mulanya dikembangkan kawasan Melayu Serantau merupakan nenek moyang jenis musik ini. Cakupan wilayah yang dimaksud adalah seputar kedua belah pantai Sumatra (pantai barat dan timur) dan tanah Semenanjung. Di pantai barat Sumatra, musik ini memperoleh pengaruh lokal dan berkembang secara khusus dengan sebutan gamat. Di belahan lain, di pantai sebelah timur Sumatra, khususnya di wilayah Deli dan Semenanjung, musik ini berdinamika, kemudian dikenal sebagai musik Melayu Deli. Ciri khas musik ini adalah pada hentakan perkusinya, yakni dari alat musik kendang. Disamping itu, unsur dominan lainnya adalah adanya akordeon dan biola yang dimainkan oleh beberapa pemain.

Pada masa kolonialisme awal, belum bisa dipastikan kapan tepatnya, banyak orang Melayu yang bermigrasi ke Batavia dengan membawa serta tradisi bermusiknya. Di ibukota Hindia Belanda ini, alunan musik mereka kemudian terkenal dengan nama irama Melayu Jakarta/Betawi. Kendati masih didominasi oleh aransemen Melayu Deli, perlahan, jenis musik ini menampilkan wajah yang lebih elastis sehingga reseptif terhadap unsur baru.

Memasuki tahun 1940-an, Gambus muncul sebagai jenis musik yang populer 
disamping Keroncong dan Hawaian. Gambus sendiri merupakan peraduan dari musik Melayu dan sedikit sentuhan musik Arab dan Asia barat. Memasuki 1951, seiring dengan populernya penggunaan radio, musik gambus tampil dengan warna kemelayuan yang amat pekat. Beberapa grup musik OM (Orkes Melayu) mulai bermunculan dan mengorbit, seperti OM Bukit Siguntang, OM Kemala, OM Sinar Kemala dan lain-lain. Dalam bentuknya yang paling sederhana, grup musik ini terdiri dari rebana (semacam drum kecil), kemung (gong kecil) dan akordeon.

Di masa itu pula, musik Melayu mengalami pengaruh lain, yakni aliran India, yang masuk karena mengambil momen dengan semakin populernya filmfilm India. Kombinasi ini amatlah terasa ketika didendangkanya lagu Boneka dari India ciptaan Husein Bawafie pada 1951, yang dinyanyikan Ellya Khadam. Lagu ini dikenal sebagai lagu dangdut pertama, meskipun penyebutan dangdut kala itu belumlah populer. Penggunaan tabla (jenis drum asal India) yang merupakan warisan pengaruh India, belakangan menjadi ciri khas dangdut di kemudian hari. ${ }^{24}$

Musik dangdut baru menemukan bentuk khasnya ketika tampil seorang bernama Oma Irama - belakangan dikenal sebagai Rhoma Irama - pada tahun 1963.Oma bergabung dengan grum OM Purnama pada tahun 1968. Dalam satu kesempatan namanya kian mengorbit setelah menyanyikan lagu Ke Binaria yang dinyanyikannya bersama Elvi Sukaesih. Pada 1971, Oma memutuskan membuat grup sendiri bernama OM Soneta yang bersamanya, nama Oma semakin merangkap naik. Oma mengadakan perombakan aransemen cukup radikal, yakni dengan mengubah ciri khas musik Melayu yang biasanya ddihiasi dengan hentakan kaki, maka Oma mencampurkan pengaruh rock pada dangdutnya, sehingga

\footnotetext{
${ }^{24}$ Moh. Muttakin, "Musik Dangdut dan Keberadaannya di Masyarakat:Tinjauan dari Segi Sejarah dan Perkembangannya" dalam Harmonia, Vol. VII no. 2, Mei - Agustus 2006, hlm. 22 - 25.
}

pedengarnya serasa diajak bergoyang sampai melepaskan alas kakinya. ${ }^{25}$ Belakangan musik dangdut menjadi semakin populer, dengan beragam jenisnya seperti Dangdut Latin, Dangdut Sunda, Disko Dangdut ${ }^{26}$, bahkan hingga varian Dangdut Koplo.

\section{Kesimpulan}

Semakin menjamurnya musik-musik turunan dangdut, tidak terlepas dari akar keelastisannya di masa lampau. Ternyata, islamisasi bukan sebatas pada perubahan cara ibadah maupun cara hidup, melainkan mempengaruhi pula cara berpikir dan berkreasi. Kesenian ini amatlah peka zaman, sehingga tidak langsung memusykilkan pengaruh Melayu didalamnya. Walaupun zaman kian berubah, daya cipta yang terbentuk dari bahana Melayu akan senantiasa memunculkan kebaruan.

\section{Daftar Pustaka}

Al-Attas, Syed Muhammad Naquib. Islam dalam Sejarah Kebudayaan Melayu. Bandung: Mizan, 1990.

Azra, Azyumardi, ed. Perspektif Islam di Asia Tenggara. Jakarta: Yayasan Obor Indonesia.

Jaringan Ulama. Jakarta: Kencana, 2007.

Drewes, G.W.J. "New Light of Coming of Islam to Indonesia", BKI (Bijdragen tot de Taal, Land-en Volkenkunde), 124. 1968.

Dunn, Ross E. Petualangan Ibnu Batutta Seorang Musafir Muslim Abad 14, terj. Amir Sutaarga. Jakarta: Yayasan Obor Indonesia, 2011.

Fairservis Jr, Walter A. Asal-Usul Peradaban Orang Jawa dan Tiongkok, Terj. Anwar. Surabaya: Selasar Surabaya Publishing, 2009.

\footnotetext{
25 William H. Frederick, "Goyang Dangdut Oma Irama: Aspek-Aspek Kebudayaan Pop Indonesia Kontemporer" dalam Ectasy Gaya Hidup (Bandung: Mizan, 1997) hlm. 110 dan 263; lihat juga Moh. Muttakin, "Musik Dangdut ...", hlm. 23-24

${ }^{26}$ Moh. Muttakin, “Musik Dangdut ...”, hlm. 24.
} 
Frederick, William H., "Goyang Dangdut Oma Irama: Aspek-Aspek Kebudayaan Pop Indonesia Kontemporer" dalam Ectasy Gaya Hidup. Bandung: Mizan, 1997.

Hurgronje, C. Snouck. Kumpulan Karangan Snouck Hurgronje IX, Terj. Sutan Maimun dkk. Jakarta: INIS, 1994.

Groneveldt, W.P. Nusantara dalam Catatan Tionghoa, Terj. Gatot Triwira. Depok: Komunitas Bambu, 2009.

Ibrahim, Ahmad dkk, peny. Islam di Asia Tenggara Perspektif Sejarah, Terj. A Setiawan Abadi. Jakarta: LP3ES, 1989.

Komroff, Manuel, ed. The Travel of Marco Polo The Venetian. New York: W.W. Norton, 1930.

Mulyana, Slamet. Runtuhnya Kerajaan Hindu-Jawa dan Timbulnya Negara-Negara Islam di Nusantara. Yogyakarta: LKiS, 2009.

Muttakin, Moh. "Musik Dangdut dan Keberadaannya di Masyarakat:Tinjauan dari Segi Sejarah dan Perkembangannya" dalam Harmonia, Vol. VII no. 2, Mei - Agustus 2006.

Nabi, Malik bin, Membangun Dunia Baru Islam, Terj. Afif Muhammad dkk. Bandung: Mizan, 1995.

Takari, Muhammad, Zapin Melayu dalam Peradaban Islam, (artikel).

Tim Penulis PUSPINDO. Sejarah Pelayaran Niaga di Indonesia Jilid II. Jakarta: Yayasan Pusat Studi Pelayaran Niaga di Indonesia, 1990.

Tjandrasasmita, Uka. Pertumbuhan dan Perkembangan Kota-Kota Muslim di Indonesia Dari Abad XIII sampai XVIII Masehi. Kudus: Penerbit Menara Kudus, 2000.

Van den Berg, L.W.C. Orang Arab di Nusantara, Terj. Rahayu Hidayat. Depok: Komunitas Bambu, 2010.
Wolters O.W. Kemaharajaan Maritim Sriwijaya di Perniagaan Dunia Abad III - Abad IV, Terj. Edy Sembodo (Depok: Komunitas Bambu, 2011. 
450 Al-Turāśs Vol. XIX No. 2, Juli 2013 
M. Dien Madjid: Arab-Melayu dalam ... 451 
